\title{
Revolts and Political Violence in Early Modern Imagery
}

\author{
Malte Griesse, Monika Barget, and David de Boer
}

In recent years, the Islamic State (Is) has repeatedly shocked audiences all over the globe with imagery of dreadful violence. ${ }^{1}$ Those who have seen the execution videos of James Fowley and other prisoners, or the photos of Abu Abdel Rahman al-Iraqi posing in front of the impaled heads of his victims, will hardly ever forget them. It is not the graphic nature of the violence alone that makes a lasting impact. Other important factors were the unexpected immediacy with which these videos, virally disseminated on social media, hit us, and the seeming similarities to popular works of fiction in the West. ${ }^{2}$ Many television series present us with remarkably graphic violence, but because it is fictional and embedded in a familiar genre, we perceive and assess it differently. The similarities and differences between real and fictional violence in our current media landscape became painfully tangible when Rod Stewart had to apologize for posting a video in which he jokingly reenacted an execution. It was supposed to be a reference to Game of Thrones, but people associated it with Is. $^{3}$

Whether or not we approach depictions of violence with pleasure, fear, or disgust does not depend on the iconography alone but derives from the communicational context. Apart from the relationship between image and reality, our social environment, genre conventions, and connections with those who produce or disseminate the imagery have an effect on our reactions. Receptions of violence are therefore not only intuitive and immediate, but they also transcend the event itself. Conventions of acceptable or improper performances and representations of violence have evolved over long periods of time and are shaped by cultural transfers and innovations in media production.

Western commentators often argue that the execution practices of Is' fighters were "medieval." ${ }^{4}$ Such judgments are more rooted in stereotypes about

1 Bernhardt, Bildstrategien der Terrormiliz 'Islamischer Staat."

2 Allen, "Aniconism and Figural Representation in Islamic Art."

3 See Grierson, "Sir Rod Stewart Says Mock Execution was Game of Thrones Prank."

4 The Washington Post, for instance, characterized Is propaganda as a "medieval reality show"; see Miller und Mekhennet, "Inside the Surreal World of the Islamic State's Propaganda Machine." 
the European past than profound knowledge of modern Islamism. Within this narrative, "medieval" serves as a synonym for archaic or barbarian, making terrorists the enemies of the modern world. ${ }^{5}$ However, the larger context of IS' communicational objectives reveals that these strategies mirror a more recent tradition. Although visual representations of executions did exist in the Middle Ages, they became widespread only with the advent of the print revolution of the early modern period. From the fifteenth century onward, woodcuts and later engravings representing - or claiming to represent - real-life executions with graphic detail became increasingly common. In early modern Europe, executions were almost routinely visualized and disseminated, often by the punishing authorities themselves, who wanted to demonstrate their power, at first glance a direct parallel to Is' use of imagery, albeit in different media.

In this light, Hannah Kozlowska perhaps made a more apt comparison in the New York Times when she likened the James Foley execution video to a "modern guillotine execution spectacle, with YouTube as the town square." What this comparison unintentionally implies is that explicit visual communication of violence inflicted on human bodies stems to a considerable extent from a European tradition, even though these regions are often idealized as the cradle of modern civilization and restrained violence. And, indeed, it appears that in Orthodox Christianity and non-Christian cultures, including those dominated by Islam, such visual representations were virtually unknown, at least in print media. ${ }^{7}$

New research has offered compelling insight into the role of visualizations of pain and torture in early modern Christian devotion, especially, and the emotive responses such works could engender. ${ }^{8}$ This volume takes this burgeoning historiography into a new direction by exploring the ways in which early modern people visually communicated political violence and by gauging the effect and influence of such imagery on early modern society. By "political

5 See, for instance, Feldman, "Islamic State's Medieval Morals." For the idea of "othering," even though he does not use the term yet, see Said, Orientalism. The classic work on the enormous difference of punishment practices in the premodern and in the modern ages is, of course, Foucault, Surveiller et punir.

6 Kozlowska, "Should We Be Seeing Gruesome Acts? And If So, Where?"

7 Similarly, restrictive approaches to figural representation on many levels are also known in Byzantine and Judaic visual cultures. Islam included a broader variety of figural traditions as the faith spread, but in contrast to Western print culture, explicit depictions of exposed (naked or wounded) human bodies remained rare; see Allen, "Aniconism"; Ali, "The Royal Veil."

8 Terry-Fritsch, Beholding Violence in Medieval and Early Modern Europe; Graham and KilroyEwbank, eds., Visualizing Sensuous Suffering and Affective Pain in Early Modern Europe; Decker and Kirkland-Ives, Death, Torture and the Broken Body in European Art, 1300-1650. 
violence" we mean violence that is carried out by or directed against a government, or between social groups, to consolidate or change the power relations in a certain polity. ${ }^{9}$ Although many studies have covered isolated aspects of the communication of political violence and punishment in the early modern period (e.g., individual works of art or specific practices), this book is the first to offer a broad contextualization from the Protestant Reformations to the Age of Revolution and transcend the confines of Western Europe.

Tracing the genealogy of imagery of political violence across time and space, the contributors to this volume explore questions that remain highly relevant in our media landscape today, and they critically evaluate the implicit but prevalent bias towards Western European material. What role did representations of political violence play in premodern societies, and how did this change with the rise of the printing press? How was violent imagery used to legitimize or contest political structures, and did governments and oppositional groups follow different visual strategies? To what extent was there a cross-border and transcultural exchange of techniques, materials, genres, conventions, and specific imagery, and how was this affected by changing political, social, and infrastructural landscapes? Indeed, how entangled or isolated were distinct visual cultures in this period of increasing interregional communication, early globalization, and European colonization?

To engage with these questions, we will explore different genres and modes of visual representation, from highbrow art to cheap prints produced for broad circulation. In doing so, we tie in with "visual culture studies," which have abandoned the narrow focus of traditional art history on the aesthetic quality and market value of artworks. ${ }^{10}$ Instead, works of art from almost any period and of very different quality and recognition have become valuable sources for cultural historians, literary scholars, and even sociologists. ${ }^{11}$ Centuries before digital media made it possible for almost everyone to visually communicate with potentially infinite numbers of recipients, different strata of society could publicly express diverging opinions in rituals, artefacts, drawings, paintings, or print. Accordingly, this volume covers a wide range of imagery, from orally

$9 \quad$ For a conceptual analysis, see Bosi und Malthaner, "Political Violence."

10 Harms und Schilling, Das illustrierte Flugblatt der frühen Neuzeit. Even before the proclamation of "pictorial" or "iconic" turns under the premises of explicit interdisciplinarity, fascinating research on early modern pamphlets and the circulation of woodcuts and engravings has developed at the interface of media studies and art history. Kunzle, The Early Comic Strip. See also the interdisciplinary Journal of Visual Culture, founded in 2002.

11 For sociology, see Pauwels "Taking the Visual Turn in Research and Scholarly Communication Key Issues." 
or textually transmitted mental images to illustrated manuscripts, anonymous folk art, and internationally esteemed engravings by famous artists. Moreover, putting visualizations of political violence at its center, this volume sheds new light on the historiography of early modern revolts as communicative events, in which the use of textual sources remains dominant. ${ }^{12}$

Then as now, almost all visualizations of violence carried a normative message. First of all, it is important to bear in mind that societies made a notable distinction between violence and cruelty. ${ }^{13}$ In the early modern period, violence was almost universally accepted as necessary to restore law and order. ${ }^{14}$ The monopoly on violence of central governments only gradually evolved in the process of European state formation. Prior to the eighteenth century, aristocratic courts and other representatives or holders of worldly authority often interacted with a variety of local agents in the resolution of violent conflict, which is reflected in the imagery produced. ${ }^{15}$ When the state carried out legal violence, audiences were often present. Executions were seen as a reestablishment of violated social order in their own right. Performing them publicly was therefore an important act of political communication. ${ }^{16}$ Visual accounts were also means for authorities to claim legitimacy and call for the viewers' consent and acclamation. ${ }^{17}$

When violence was deemed cruel, abhorrence and rejection were implied; the term referred to disproportional, excessive, or unjustified violence. ${ }^{18}$ However, it is hard to say at what stage contemporaries considered violence excessive. ${ }^{19} \mathrm{To}$ our modern eyes, early modern punishments and the enormous variety of executions seem inhumane. Early modern authorities, however, often propagated painful executions in print. Very graphic and revolting depictions of violence could convey much more rational messages than modern stereotypes about

\footnotetext{
12 A good summary of the development of revolt historiography, especially for the seventeenth century, can be found in Benigno, Mirrors of Revolution.

13 Pawlak und Schankweiler, "Ästhetik der Gewalt - Gewalt der Ästhetik."

14 Lovell, Justice and Mercy Equal Supporters of the Throne.

15 Ruff, Violence in Early Modern Europe, 1500-1800, 2.

16 Yetter, Public Execution in England, 1573-1868.

17 William Jackson, The New and Complete Newgate Calendar, or, Villany Displayed in All its Branches.

18 Aston, Satan in Samuels Mantle, or, The Cruelty of Germany Acted in Jersey.

19 See Baraz, Medieval Cruelty.
} 
early modern times will allow. ${ }^{20}$ In fact, we will come to see that cruelty was often defined not by the nature of the violence itself, but by the perceived innocence or guilt of the executed. For instance, Dutch poet Joost van den Vondel lamented the political execution of Lands' Advocate Johan van Oldenbarnevelt by stadtholder Maurits as cruel, even though he had only been beheaded, a relatively quick and painless way to die on the early modern scaffold. ${ }^{21}$

Early modern authorities could prepare and frame the actual setting of public punishment and thereby shape context to some extent. But they had less control over how prints were received. Visual conventions were not without ambivalence and not always accepted by early modern spectators. Reconstructing these visual conventions and markers of legitimacy surrounding images of violence, we explore the boundaries of what denoted illegitimate cruelty in the complex interplay between act, representation, and reception.

Conditions of art reception are generally much more difficult to trace than those of art production and the media policy of political authorities. As a consequence, only a few writers have so far explored modes of reception. One of the rare examples of an investigation of esthetic guidelines for spectators is Fee-Alexandra Haase's study of the topoi of evaluation in contemporary reviews of history painting. However, Haase's object of study, the journals that systematically published art reviews, only began appearing in the later eighteenth century and reflected the viewpoints of an educated audience. ${ }^{22}$ For earlier periods, we know strikingly little about patterns of perception in highbrow art, let alone those in cheap prints made for rapid circulation. Pre1700 theoretical and historical reflections on art, such as Giorgio Vasari's Lives of the Most Excellent Painters, Sculptors, and Architects (1550) or Cesare Ripa's Iconologia (1593), can prove insightful because these works reveal the fragility and dissension in modes of visual perception. ${ }^{23}$ Explicit contemporary reflections on visual culture are, however, not the only tools that historians can apply to understand the perceptual horizons of people in the early modern world. As Michael Baxandall reminds us, if we want to understand how contemporaries assessed images, we also need to scrutinize how their social world visually conditioned them. The cognitive style of, say, seventeenth-century Portuguese

20 An attempt to look beyond gory punishments and explain the complexity and intrinsic logic in early modern approaches to violence and criminal justice was, for instance, made in Rousseaux, "Crime, Justice and Society in Medieval and Early Modern Times."

21 van den Vondel, "Het stockse van Johan van Oldenbarnevelt."

22 Haase, "Topik und Kunstrezension."

23 See, for instance, Giovanni Battista Passeri's (1610-1679) complaints about endless arguments on style and meaning in the seventeenth century; quoted in Sohm, Style in the Art Theory of Early Modern Italy, 19. 
merchants were different from ours, making them perceive visual material differently. ${ }^{24}$ Many art historians in Germany have adopted the "aesthetics of reception" from the School of Constance, which is dedicated to finding the implicit, that is, anticipated, reception in the work of art itself. ${ }^{25}$ They depart from the idea that artists were able to foresee different reception settings and address more than one audience at a time.

In congruence with this approach, Peter J. Burgard has described the "desacralization of the sacred" in paintings by Caravaggio, Bernini, and Asam. Burgard argues that early modern Western European art saw a constant development towards ambiguity that peaked in the mid-seventeenth century. ${ }^{26} \mathrm{~A}$ single painting or drawing could suggest more than one meaning, and different layers often playfully or dramatically contradicted each other. The contributions to this volume will show that ephemeral woodcuts or engravings, though often appearing to have been less carefully designed, could convey similarly ambiguous messages.

Many scholars in the 1950s and 196os underestimated the ability of contemporary audiences to consciously decipher, judge, or even deconstruct visual messages. But images did not travel in one direction only. Early modern media were often subjected to appropriation, recontextualization, and ridicule as warring parties could attain equal access to printing sources and visually oppose each other's opinions in physical or "mental images."27 Of course, visual literacy could differ starkly between social groups. Peasants from remote villages and ordinary city dwellers, who were mostly illiterate, certainly did not share the visual interpretational tools of erudite hommes de lettres. Yet this did not necessarily exclude them from consuming such media. Our modern reading habits are highly individualized - even though social networks allow for instant virtual exchange - but in the early modern period texts and images were often read and interpreted in groups, or even publicly in the marketplace. ${ }^{28}$

24 Baxandall, Painting and Experience in Fifteenth Century Italy; Baxandall, Patterns of Intention.

25 Hans Belting's work on the medieval imago pietatis is an important example, since the images were definitely used for devotional purposes. See Belting, Das Bild und sein Publikum im Mittelalter; Michael Fried, Absorption and Theatricality.

26 Burgard, "Desacralization of the Sacred: Caravaggio, Bernini, Asam"; Rosen, Der stumme Diskurs der Bilder. Other works corroborate his findings. See, for instance, Clark, Vanities of the Eye.

27 For the concept of mental images in visual culture studies, see Belting, Anthropology of Images. In the present study, it is mainly Galina Tirnanić who builds on this concept.

28 Rheingold, Smart Mobs. 
The literate, or in towns even professional news criers, read the texts to the assembled public and explained its pictures. ${ }^{29}$

A case in point is a Dutch pamphlet showing the execution of three conspirators who had tried to assassinate stadtholder Maurice of Orange in 1623. Below the image is a fictional conversation between a peasant and his landlord about the news. The peasant tells the nobleman that he has seen a pamphlet commenting on the execution, but he cannot read. The landlord then offers to read the pamphlet to him, which takes the form of a step-by-step explanation of the image. The peasant is so impressed by the news that he immediately wants to head to a bookseller and buy a copy of his own, which he wants to show to his neighbors who dislike the stadtholder. ${ }^{30}$ This should also remind us that recognizing the importance of images in communicating revolt and punishment in early modern times should not lead us to overcompensate and study them in isolation from text. The two modes of communication were often heavily intertwined. Broadsides and pamphlets often combined picture and text, and they included captions or more substantial and independent narratives, such as poems. ${ }^{31}$

\section{$2 \quad$ Image and Reality}

The extent to which images reflect reality is an age-old question. The performance of political violence could diverge wildly from its visual representations in print, which came with its own codes and grammar. For instance, well into the nineteenth century, execution broadsides were often sold shortly after the public punishment, which meant that they had to be produced in advance. Such images were therefore rather stylized and generic. ${ }^{32}$ Prints and paintings produced, not as news media, but as visual historiography or mementos to individual historic figures were, by contrast, more likely to highlight remarkable details. ${ }^{33}$ Visual representations of violence may thus be more reflective of an assumed choreography or commemorative purpose than of what "actually" happened. Often relying on traditional symbolism and language, many images reflect more of the contexts in which they were produced than of the events they depicted.

29 Croft, "Libels, Popular Literacy and Public Opinion in Early Modern England."

$30 \quad$ See "De drie hoofdrolspelers in de samenzwering tegen Maurits."

31 The term "visual literacy" was coined by Debes, "Some Foundations for Visual Literacy."

32 Chassaigne, "Popular Representations of Crime."

33 See depictions of the executions of Charles I or Mary, Queen of Scots, over time. 
Working in the footsteps of Aby Warburg, theorists such as Ernst Cassirer, Heinrich Wölfflin, and Erwin Panofsky therefore did not interpret pictures as secondary expressions of external objects and ideas. Instead, they highlighted art's own semantics and placed art on the same reflective level as texts. In his concept of "iconology" Panofsky attributed several layers of meaning to images and valued their formal conventions as much as the divergent theological, philosophical, or political conceptions they could convey. ${ }^{34}$ This could include decorative elements in broadsides reflecting their content, the elaborate framing of printed portraits, or the size and position of images used as text illustrations.

Of course, images can nevertheless also be used as historical evidence. In his stimulating plea for the use of imagery by "plain historians," Peter Burke compellingly makes this point by stating that "certain historical problems are illuminated more brightly by images than by texts." ${ }^{35}$ For instance, he points out that engravers frequently recycled the same templates to represent different actors and events, which tells us something about contemporary approaches to time, place, and personhood. If we compare this with much more elaborate painted portraits, it can furthermore give us insight into the extent to which such approaches were universal or genre-dependent. ${ }^{36}$ To name an example, engravers often created Simultanbilder, an integrated comic strip in which several subsequent events are depicted within one composition, to tackle the temporal dimensions of an event. In the Dutch Republic, Simultanbilder were popular in print but very rare in paintings, which were governed by other visual conventions.

In short, the artistic search for truth could have very different outlooks; truth could be perceived as a realistic depiction of a specific moment in time (enabling secondary eyewitnessing), but also as a metaphysical truth. In this light, we should be careful not to approach images that reflect little of what "actually happened" as mere propaganda. ${ }^{37}$

34 Scribner, For the Sake of Simple Folk, xvi.

35 Burke, "Interrogating the Eyewitness."

36 A more elaborate and very intriguing study on the human face, the mask, and concomitant conceptions of personhood over the ages, which discusses early modern portraiture in this broader context, can be found in Belting, Faces.

Gill, "All Art is Propaganda"; Orwell and Packer, All Art is Propaganda. 


\section{Tracing the Iconography of Violence in the Early Modern World}

The first section of this book, Visual Markers of Legitimacy, explores how rulers and rebels from different geographical and iconographical contexts tried to consolidate their authority through visual markers. Ya-Chen Ma's chapter on representations of revolts in early Qing China and Galina Tirnanićs chapter on medieval Byzantium show that in contrast to the general practice of staging executions publicly in presence of an audience, visualizing these punishments for a larger distant public was not a universal strategy. But although images of violence did not publicly circulate in Byzantium and China, acts of violence were nonetheless commemorated.

Drawing on visual series commissioned by high-ranking officials to commemorate their careers in both the Ming and the Qing period, Ya-Chen Ma explores the visualization of counterinsurgency campaigns. Contained in the galleries of officials, they were shown in private circles. Circulation was limited, but the production of these images sometimes entailed global transfers, for instance when engravings for private use in China were printed in Paris through Jesuit mediation in the 1770s. Tirnanić shows that bodily mutilation was an important means of permanently reminding the punished and those who saw him of his crimes and of the state's authority. Such punishments were enacted in designated ritual public places. Being familiar with the architectural space, this allowed people to form a mental image of the punishments, regardless of whether they had actually been present. In other words, imprinting images of punishment on a large population did not necessarily require the printing press or even paper.

The medieval Byzantine visualization of revolts stands out because it belongs to the pre-Gutenberg era. But even after the print revolution, Qing China and the Ottoman successors of the Byzantine Empire were practically devoid of printed media. China could draw on a much longer regional history of printing than European countries, and transfers in terms of technical reproduction preceded Western imperialist interference. Yet without the privatization and commercialization of the postal system and the trigger of the deep confessional divide, China did not develop the same culture of mass printing. ${ }^{38}$

Images had the property of depicting and shaping a desired reality, and repeated physical depictions helped create mental images of power. They not only reaffirmed the status quo of those in power, but could also help those who sought it, anticipating reality. Alain Hugon's chapter is devoted to the role of images in revolutionary ceremonies, including rites of execution. He shows 
how the insurgents in the Neapolitan revolt of $1647^{-1648}$ mobilized pictures to legitimize and gain support for their new "regime," no matter how rudimentary this was in institutional terms. The Neapolitan use of images and the Byzantine case illustrate how both established authorities and an emerging insurgent power tried to shape lieux de mémoire, be they fixed in place or highly mobile as were the icons carried in procession in Naples.

Section Two, Confessional Conflict, addresses visual representations of interconfessional violence in the wake of the European Reformations. The rise of printed media in Western Europe was the result of a technical revolution, but it also went hand in hand with the emergence of a culture of public persuasion during Europe's age of confessional conflict. ${ }^{39}$ Ramon Voges' chapter on the influential newsprints of Frans Hogenberg in the early phases of the Dutch Revolt explores how the artist represented recent events and tried to influence the course of the conflict. Through different visual cues, Hogenberg notably tried to deconfessionalize the revolt and encourage spectators from different religions to adopt a moderate political stance. Voges reveals that although the prints were clearly intended to persuade, imagery circulating during the wars of religion cannot be reduced to mere propaganda. Hogenberg was not commissioned by either of the warring parties. Moreover, consumers of his images had to pay close attention to understand the subtle symbolism and arrangement of historical actors.

The wars of religion also gave rise to new expressions of transnational solidarity, and publishers played a key role in creating an early humanitarian culture. Focusing on images of the 1655 massacre of the Reformed Waldensians in Piedmont, David de Boer investigates how Dutch pamphleteers used different visual strategies to make consumers identify with persecuted minorities abroad. He shows that by copying images and visual templates from earlier confessional conflicts that were important in Dutch cultural memory, printmakers framed the massacre as part of a larger struggle that transcended time and space. De Boer shows that the inevitable ambiguity of imagery also provided opportunities for printmakers. It allowed them to make visual references that could not be easily made in textual accounts.

Voges and de Boer show that insurgents often depended on third parties for visual representation. This point is further elaborated upon by Malte Griesse, who shifts focus to the Counter-Reformation in Habsburg territories and the resistance of the Upper Austrian Protestant population against reCatholicization. The so-called Peasants' War of 1626 was staged by peasants,

39 See Burkhardt, Das Reformationsjahrhundert; Pettegree, Reformation and the Culture of Persuasion. 
who had little political agency and means to promote their cause under ordinary circumstances. In their place, exiled Protestant nobles played a leading role in promoting and shaping the image of the insurgents in the free cities of the Holy Roman Empire, presenting it as a crucial part of what would come to be known as the Thirty Years' War. Griesse shows that the communication of confessional identity and resistance against foreign rule led to a protonationalist sentiment that shaped both the conflicts themselves and the imagery they engendered. Together, the strategies of confessionalization and deconfessionalization discussed in these chapters shed light on how images were used to target specific audiences and shape long-distance communities in an emerging mass media landscape.

Section Three, Foreign Observation, explores the international dimensions of visual strategies of legitimation and delegitimation and analyzes how rulers and rebels communicated their cause across borders. In their contribution on the Thököly Uprising of 1682, Nóra Etényi and Monika Barget show how the Habsburg dynasty visually discredited insurgents who also had access to the printing press. Even though Protestant powers in the Holy Roman Empire depicted oppositional Hungarian noblemen in a positive light and criticized the emperor, imperial visual strategies were far more efficient than the rebels' printing campaign.

Once militarily victorious, insurgents still often had to win a battle for legitimacy, as becomes clear from Joana Fraga's contribution on the Portuguese Restoration. Fraga shows how after secession from the Spanish Habsburgs, the new monarchy realized that disseminating royal imagery abroad was crucial for acquiring international legitimacy and counteracting the reputation of the Portuguese as rebels. In the course of their, initially unsuccessful, attempt to gain international recognition, Portuguese nobles distributed portraits of King John (João) IV in Europe's main capitals. They were presented with the daunting task of creating an internationally easily recognizable visual language of royal continuity, while at the same time showing the hardships of Habsburg oppression.

Eastern European rulers and rebels typically did not fight such image offensives, even though leaders of the big Cossack uprisings in Muscovy and Ukraine certainly sought foreign support from sovereigns, from Europe to Persia, in some cases with astonishing success. Still, textual and visual representations of political violence in Muscovy and Ukraine did appear in Central and Western European media, as diplomats, merchants, and Western specialists observed carefully what was going on in these lesser-known parts of Europe. Of course, such representations were hardly neutral. Nancy S. Kollmann analyzes one of the rare images of a punishment scene in seventeenth-century Muscovy, which 
was published in Adam Olearius' Voyages and Travels in the 1630 . Comparing the picture with contemporary representations of punishments in Central and Western Europe, Kollmann argues that its unorderly setting was intended to convey the idea of a despotic regime. The printmaker consciously left out officials and spectators supervising and witnessing the executions, creating a seminal image in the West of an Eastern society dominated by arbitrary violence.

As Gleb Kazakov's contribution reveals, a similar tendency can be observed in Western European representations of Muscovite rebels. Exploring images of the Cossack Rebellion of 1670-1671, Kazakov shows how the conflict was orientalized. In the absence of Russian visualizations of the revolt, European printmakers built on visual tropes of the Islamic world. Western media thus depicted the Cossack rebel Stepan Razin as an Ottoman. Kazakov points out, however, that this implicit discrediting of the rebels as allies of Christendom's archenemy did not necessarily entail a rehabilitation of the government against whom the insurgents were fighting. Within Western visual stereotypes of a chaotic East, there was a soft boundary between legitimate and illegitimate rule.

Section Four, Revolutionary Images, moves on to the eighteenth century, when visualizations of state power and violence had to conform to Enlightenment criticism. Monika Barget's contribution is dedicated to the iconography of leadership in the American Revolution. Explaining conventions of eighteenth-century royal portraiture in the British Empire, she shows the difficulties of representing a nascent democratic order. In both North America and Britain, political portraits eventually stressed soldierly and civic virtues over social status and inherited rights, but aristocratic ideals were revived in the face of the French Revolution.

A complex and often ambiguous history of societal change and political emancipation is also told in the representations of the Haitian Revolution, which Fabian Fechner discusses in the final chapter. Enslaved African Americans and Native Americans were excluded from political agency in the United States and most Latin American countries, but people of color played the leading role in the history of Haitian independence. In fact, almost all white slaveholders were killed or forced from the country. Fechner explores the visual codes of a colonial world turned upside down. Visualizations of anticolonial rebellion turn out to be extremely scarce, which matches Sybille Fischer's influential thesis on the Haitian taboo. ${ }^{40}$ The graphic images that were produced mainly criticized the abolition of slavery in the wake of the French Revolution. 
Rather than showing the cruelty of slavery, they, for instance, depicted Black Haitian soldiers hanging white French soldiers.

In the course of the nineteenth century, executions in Western Europe were gradually removed from the public realm..$^{41}$ Correspondingly, exceptional depictions of executions generally lamented the represented act. Francisco Goya's famous series of prints, The Disasters of War (1810-1820) and his painting The Third of May (1818), to name two well-known examples, denounce the represented executions as barbarism and were meant to incite indignation. But Goya's representations, too, were part of the European visual tradition. Indeed, his prints show striking similarities with Jacques Callot's 1633 The Great Miseries of War, which also represents violence in an unglorified manner. ${ }^{42}$

Europeans increasingly let go of visually representing just punishments, but images of violence in print media from other regions only increased. The United States, for example, retained a culture of public executions and lynchings for another century, and their visual representations were disseminated through lynching postcards. ${ }^{43}$ Colonial violence in Africa and Asia also became frequent news items. Although many Western media justified white supremacy through bloody displays of indigenous warfare, Christian missionaries and European scientists traveling the colonies also began to report home white cruelty towards enslaved people. ${ }^{44}$ In a globalizing world, visualizations of violence became virtually inescapable.

This visual shift took place in the eighteenth and nineteenth centuries, so most people today looking at the images presented in this book will not intuitively judge the represented scenes to be acts of justice, even though in many cases this was certainly the intention of the print producer. At the same time, the events and their modes of portrayal often seem so far from our everyday reality and visual culture that they fail to have the same affective effect on the modern spectator as they made on contemporary consumers. After all, these prints were produced in visual languages very different from ours. By translating and contextualizing these works, the following chapters can therefore provide insight into more than the societies in which they were produced. They also invite readers to compare and contemplate the visual cultures that we consume and create in today's globalized and digital media landscape.

\footnotetext{
41 Foucault, Surveiller et punir.

42 See Hood Museum of Art, Fatal Consequences.

43 Allen, Without Sanctuary.

44 Cutter, The Illustrated Slave.
} 


\section{Bibliography}

Ali, Nadia. "The Royal Veil:Early Islamic Figural Art and the Bilderverbot Reconsidered." Religion 47, no. 3 (July 2017): 425-444.

Allen, James. Without Sanctuary: Lynching Photography in America. Santa Fe, NM: Twin Palms, 2000.

Allen, Terry. "Aniconism and Figural Representation in Islamic Art." In Five Essays on Islamic Art, translated by Terry Allen, 17-37. Sebastopol, CA: Solipsist Press, 1988.

Aston, Sir Thomas. Satan in Samuels Mantle, or, The Cruelty of Germany Acted in Jersey: Containing the Arbitrary, Bloody, and Tyrannical Proceedings ofJohn Mason ... against Several Officers and Souldiers in That Small Place: As Also His Earnest Endeavours to ... Encourage the Army in England, Jersey, and Garnzey in Their Rebellion against the Parliament. London: T. R., 1659.

Baraz, Daniel. Medieval Cruelty: Changing Perceptions, Late Antiquity to the Early Modern Period. Ithaca, NY: Cornell University Press, 2003.

Baxandall, Michael. Painting and Experience in Fifteenth Century Italy: A Primer in the Social History of Pictorial Style. 2nd ed. New York: Oxford University Press, 1988.

Baxandall, Michael. Patterns of Intention: On the Historical Explanation of Pictures. New Haven, CT: Yale University Press, 1985.

Belting, Hans. Anthropology of Images. Princeton, NJ: University Press Group Ltd., 2011. Belting, Hans. Das Bild und sein Publikum im Mittelalter: Form und Funktion früher Bildtafeln der Passion. Berlin: Mann, 1981.

Belting, Hans. Faces: Eine Geschichte des Gesichts. 2nd ed. Munich: C.H.Beck, 2014.

Benigno, Francesco. Mirrors of Revolution: Conflict and Political Identity in Early Modern Europe. Turnhout: Brepols, 2010.

Bernhardt, Petra. "Bildstrategien der Terrormiliz 'Islamischer Staat." In Bildmacht/ Machtbild:Deutungsmacht des Bildes: Wie Bilder glauben machen, edited by Martina Kumlehn and Philipp Stoellger, 199-212. Würzburg: Königshausen \& Neumann, 2018.

Bosi, Lorenzo, and Stefan Malthaner. "Political Violence." In The Oxford Handbook of Social Movements. https://doi.org/10.1093/oxfordhb/9780199678402.013.50.

Briggs, Asa, and Peter Burke. A Social History of the Media: From Gutenberg to the Internet. 3 rd ed., repr. Cambridge: Polity Press, 2010.

Burgard, Peter J. “Desacralization of the Sacred: Caravaggio, Bernini, Asam.” In Erosionen der Rhetorik? Strategien der Ambiguität in den Künsten der Frühen Neuzeit, edited by Valeska von Rosen, 303-320. Wiesbaden: Harrassowitz Verlag, 2012.

Burke, Peter. "Interrogating the Eyewitness." Cultural and Social History 7 (2010): $435^{-444 .}$ 
Burkhardt, Johannes. Das Reformationsjahrhundert: Deutsche Geschichte zwischen Medienrevolution und Institutionenbildung, 1517-1617. Stuttgart: Kohlhammer, 2002.

Chassaigne, Philippe. "Popular Representations of Crime: The Crime Broadside - a Subculture of Violence in Victorian Britain?" Crime, Histoire \& Sociétés/Crime, History \& Societies 3, no. 2 (June 1999): 23-55.

Clark, Stuart. Vanities of the Eye: Vision in Early Modern European Culture. Oxford, New York: Oxford University Press, 2007.

Croft, Pauline. "Libels, Popular Literacy and Public Opinion in Early Modern England." Historical Research 68, no. 167 (1995): 266-285.

Cutter, Martha J. The Illustrated Slave: Empathy, Graphic Narrative, and the Visual Culture of the Transatlantic Abolition Movement, 1800-1852. Athens: University of Georgia Press, 2017.

"De drie hoofdrolspelers in de samenzwering tegen Maurits, 1623, anoniem, 1623." https://www.rijksmuseum.nl/nl/collectie/RP-P-OB-81.018A.

Debes, John. "Some Foundations for Visual Literacy." Audiovisual Instruction 13 (1968): 961-964.

Decker, John R., and Mitzi Kirkland-Ives. Death, Torture and the Broken Body in European Art, 1300-1650. Farnham: Ashgate, 2015.

Feldman, Noah. "Islamic State's Medieval Morals." Bloomberg, August 16, 2015. http:// www.bloombergview.com/articles/2015-08-16/islamic-state-s-medieval-morals.

Fischer, Sibylle. Modernity Disavowed: Haiti and the Cultures of Slavery in the Age of Revolution. Durham, NC: Duke University Press, 2004.

Foucault, Michel. Surveiller et punir: Naissance de la prison. Paris: Gallimard, 1975.

Fried, Michael. Absorption and Theatricality: Painting and Beholder in the Age of Diderot. Berkeley: University of California Press, 198 o.

Gill, Eric. "All Art Is Propaganda." Rea (Betty) 5 on Revolutionary Art 8 (1935).

Grierson, Jamie. "Sir Rod Stewart Says Mock Execution was Game of Thrones Prank." The Guardian, March 3, 2017. https://www.theguardian.com/music/2017/mar/o3/ sir-rod-stewart-mock-execution-game-thrones-isis.

Haase, Fee-Alexandra. "Topik und Kunstrezension: Argumentationselemente der deutschen Kunstkritik in zeitgenössischen Rezensionen zur Historienmalerei des ausgehenden 18. bis frühen 20. Jahrhunderts." PhD Dissertation, Universität Tübingen, 1997.

Harms, Wolfgang, and Michael Schilling. Das illustrierte Flugblatt der frühen Neuzeit: Traditionen - Wirkungen - Kontexte. Stuttgart: Hirzel, 2008.

Hood Museum of Art, ed. Fatal Consequences: Callot, Goya, and the Horrors of War. Hanover, NH: Hood Museum of Art, Dartmouth College, 1990.

Jackson, William. The New and Complete Newgate Calendar, or, Villany Displayed in All Its Branches London: Alex. Hogg, 1795. 
Kozlowska, Hanna. "Should We Be Seeing Gruesome Acts? And If So, Where?" New York Times, August 25, 2014. https://op-talk.blogs.nytimes.com/2014/o8/25/should -we-be-seeing-gruesome-acts-and-if-so-where/.

Kunzle, David. The Early Comic Strip: Narrative Strips and Picture Stories in the European Broadsheet from c. 1450 to 1825 . Berkeley, CA: University of California Press, 1973.

Lovell, Edward. Justice and Mercy Equal Supporters of the Throne. London: Tho. Corbett at the Corner of Ludgate-Hill next Fleetbridge; and sold by J. Roberts in Warwick-Lane, 1716.

Miller, Greg, and Souad Mekhennet. "Inside the Surreal World of the Islamic State's Propaganda Machine." Washington Post. November 20, 2015. https://www.wash ingtonpost.com/world/national-security/inside-the-islamic-states-propaganda -machine/2015/11/20/o51e997a-8ce6-11e5-acff-673aeg2ddd2b_story.html.

Orwell, George, and George Packer. All Art Is Propaganda: Critical Essays. 14th ed. Orlando, FL: Harcourt, 2009.

Pawlak, Anna, and Kerstin Schankweiler. "Ästhetik der Gewalt - Gewalt der Ästhetik." In Ästhetik der Gewalt - Gewalt der Ästhetik. Weimar: Verlag und Datenbank für Geisteswissenschaften, 2013.

Pauwels, Luc. "Taking the Visual Turn in Research and Scholarly Communication: Key Issues in Developing a More Visually Literate (Social) Science." Visual Sociology 15, no. 1 (2008). https://www.tandfonline.com/doi/abs/10.1080/147258600o8583812.

Pettegree, Andrew. Reformation and the Culture of Persuasion. Cambridge: Cambridge University Press, 2005.

Rheingold, Howard. Smart Mobs: The Next Social Revolution. New York: Basic Books, 2002.

Rosen, Valeska von. Der stumme Diskurs der Bilder: Reflexionsformen des Ästhetischen in der Kunst der Frühen Neuzeit. Munich: Dt. Kunstverlag, 2003.

Rousseaux, Xavier. "Crime, Justice and Society in Medieval and Early Modern Times: Thirty Years of Crime and Criminal Justice History. A Tribute to Herman Diederiks." Crime, Histoire \& Sociétés/Crime, History \& Societies 1, no. 1 (January 1997): 87-118.

Ruff, Julius Ralph. Violence in Early Modern Europe, 1500-1800. Cambridge: Cambridge University Press, 2001.

Said, Edward W. Orientalism. London: Penguin Books, 1994.

Scribner, Robert W. For the Sake of Simple Folk: Popular Propaganda for the German Reformation. Oxford: Clarendon, 1994.

Sohm, Philip. Style in the Art Theory of Early Modern Italy. Cambridge: Cambridge University Press, 2001.

Terry-Fritsch, Allie. Beholding Violence in Medieval and Early Modern Europe. Milton Park: Routledge, 2017. 
Graham, Heather, and Kilroy-Ewbank, Lauren G., eds. Visualizing Sensuous Suffering and Affective Pain in Early Modern Europe and the Spanish Americas. Leiden, Boston: Brill, 2018.

Vondel, Joost van den. "Het stockse van Johan van Oldenbarnevelt." In De Werken van Vondel, vol. 8, 1935. https://www.dbnl.org/tekst/vondoordeweo8_o1/vondoo1 deweo8_o1_o201.php.

Yetter, Leigh. Public Execution in England, 1573-1868. London: Pickering \& Chatto, 2009. 